\title{
Corporate diversification, information asymmetry and firm performance: Evidence from Tehran Stock Exchange
}

\author{
Hossein Vazifeh Dust ${ }^{\mathrm{a}}$, Fatemeh Dadbeh ${ }^{\mathrm{b}^{*}}$ and Farzaneh Hashemloo $^{\mathrm{b}}$
}

${ }^{a}$ Faculy member, Science and Research Branch, Islamic Azad University, Tehran, Iran

${ }^{b}$ Ph.D student in Financial Management, Department of Management, Science and Research Branch, Islamic Azad University (IAU), Tehran, Iran

\section{H R O N I C LE A B T R A C T}

Article history:

Received July 28, 2013

Received in revised format

22 October 2013

Accepted 28 October 2013

Available online

December 192013

Keywords:

Corporate Diversification

Firm performance

Information asymmetry

Entropy

Return on Assets

\begin{abstract}
The aim of this paper is to review the effect of corporate diversification on information asymmetry and firm performance. To test the research hypothesis, a sample of 47 companies listed in Tehran Stock Exchange over the period 2008-2012 based on panel method was taken. In these models, the presence or absence of effects models (fixed or random) is reviewed and finally the best model is estimated. The results indicate that corporate diversification using entropy influenced on information asymmetry and firm performance. With controlling other variables, the results indicate when ENTROP increases one unit, STDRET increases 0.49 unit but with controlling other variables, the results indicate when ENTROP increases or decreases one unit, ROA does not change.
\end{abstract}

\section{Introduction}

Diversification is a kind of corporate strategy for a company, which aims increased profitability through bigger sales volume obtained from new products and new markets and it is normally associated with firms with different activities and geographical diversity (Amihud \& Lev, 1981; Palich et al., 2000; Choe et al., 2009; Choe \& Yin, 2009). Some companies have no variety and some others have variety, this diversity is studied of these two dimensions: A) The geographical diversification in which company has various branches and operates in various cities and countries. In other words, it has place diversity and operates in two or more different climatic zones. In fact, each geographical part is a distinguished part of business unit, which provides goods or services in a particular geographical area consisting of a region or other geographical areas. B) Industrial diversification (commercial) in which the firm has a variety of activities and act in two or more 
segments of the market. Each business is a distinguished part of business unit, which provides a product or service or a group of related products or services (Shleifer \& Vishny, 1989, 1991).

From mid-nineteenth century, many companies have expanded their operations in terms of geographical and vertical and product (vertical and product scope) and in terms of variety of work. From 1950 to 1980, diversification, meaning expansion of the company's work into different markets, was considered a very important source of growth. Over time, the number of companies focused on a specific job was decreased while there was an increase in companies with a variety of working. From 1960 to 1970 , the trend towards diversity was the highest. Preliminary results in diversification decisions indicate that the benefit of diversification was derived from two sources. When the rate of profit was higher than the cost of capital, the profits was due to industry attractiveness and competitive advantages. Competitive decisions also include two same results:

1. How attractiveness is a part, which could be entered,

2. Whether company can achieve competitive advantages or not.

Barney and Hesterly (2008) showed that some factors could influence the trend toward diversification between 1960 and 1970. Other studies indicate that diversity in companies could reduce internal management costs. Rapid growth of management science led to this idea that extract of management was not employing experimental knowledge of one specific industry and it is to apply the tools and principles of management. Overall, the global level management principles suggest that professional management could control various firms in terms of financial figures. Subsequent research indicates companies between 1980 and 1990 have again turned into centralization. Studies show that factors such as increased volatility and turmoil in the industry, managers' centralization to increase share value, accommodate growth and the emergence of new ideas about the management of the company have been the reason for refocusing the company.

\section{Information asymmetry}

Solomon and Solomon (2004) stated that corporate managers offer most of the information published by business units and used in evaluating securities. Company managers have information about their financial circumstances that are not necessarily available to investors. This condition is known as information asymmetry. If managers regularly seek publicity information and financial data, this will reduce the gap between managers and investors. Many companies whose shares are publicly traded are required to disclose financial information and investors usually rely on financial information disclosed through official forums. On the other hand, it is possible to consider ideas of the financial experts. However, these comments may be based on financial statements provided by the firm managers. Accounting process plays an important role in the valuation process since many investors predict future earnings based on the official financial reports. Since investors use the company's cash flows to estimate its value, financial statements are influenced by valuation process that can estimate cash flows through them (Mansi \& Reeb, 2002; Matsusaka, 1993, 2001).

Sunder (1997) indicated that even at the time of disclosure, if we cannot trust some information provided by the directors of the company, there will be still the problem of information asymmetry. Billing instructions flexibility, allow manipulation of financial statements by company directors that have no commitment. Financial statements of companies' shares are publicly traded should be audited annually by certified public accountants. This asymmetry of information and the use of incomplete information provided by the firm's investors, securities may be priced incorrectly, although the internet provides greater access to information but cannot correct the misleading information provided by the managers. However, stringent laws to punish groups that are financially responsible for misleading information are ways to deal with the problem of information asymmetry. 
The literature of corporate diversification and the puzzle surrounding whether diversification leads to discount or premium, was previously surveyed by three prominent articles: Martin and Sayrak (2003), Stein (2003) and Maksimovic and Phillips (2007). Martin and Sayrak (2003) surveyed the literature on corporate diversification through two separate channels: cross sectional studies of the link between corporate diversification and firm value on one hand and longitudinal studies in patterns of corporate diversification through time on the other. Their survey suggests that diversification discount may not be the result of corporate diversification after all. In contrast, diversification discount may result from measurement issues or simply because of sample bias. Stein (2003) studied the strand of literature, which questions the efficiency of corporate investment in the presence of asymmetric information and agency problems. His focus was mainly on the literature, which addresses the issue of efficient capital allocation across firms through external capital markets and within firm allocation of capital through its internal capital market (Teece, 1980, 1982; Gomes \& Livdan, 2004).

There are many studies conducted to determine whether corporate diversification is beneficial or harmful to shareholders. Initial researches on this issue were in favor of corporate diversification. However, recent studies suggest that firm diversification reduces the value of the company. Martin and Sayrak (2003) examined the relationship between corporate diversification and effectiveness of labor and reported an inverse relationship between corporate diversification and effectiveness of the labor force. Some researchers examined the relationship between corporate environmental strategy and the value of the company and reported that the performance of the company with regard to environmental liability was entirely associated with the value of the company. Environmental liability strategy showed significantly financial responsibility for all companies except those, which had industrial customer increases. Amit (2010) examined the effect of the financial crisis in 2007 and 2009 on reduced diversification. They found that the value of corporate diversification had increased during the crisis. Diversification for companies had two benefits finance and investments throughout the course.

Other researchers examined the effect of industrial and geographic diversification on value of the company for a sample of 1,921 European firms over the period 1996-2007 where the observations led to 12427 views. Predictions of many theories, showed increase geographic diversification and decrease in industrial diversification 2.10\% and 6.7\%. Berger and Ofek (1995) used asset and sales multiplier14 instead of Tobin's Q in order to measure the value effect of diversification. In order to show the possible association between value loss and diversification they estimated pooled regressions using multi-segment dummy and control for firm size, profitability and growth opportunity of the firm. Khanna and Palepu (2000) used Tobin's Q and rate of return on assets (ROA) as a measure of firm performance. Four different diversification measures were used in their analysis: (a) INDCNT: a count of industries represented in a group, (b) ENTROPY: sum of entropy index of related diversification and an entropy index of unrelated diversification, (c) CONCENTRIC: a weighted average of each firm's share of group sales and (d) HERFINAHL: sum of squares of each industry's sales as a proportion of total group sales. Both Univariate comparisons and Multivariate regression analysis are performed using Tobin's q and ROA.

Schoar (2002) adopted a different methodology to address the issue of whether diversification destroys value or not. He used micro level data for manufacturing firms from the Longitudinal Research Database from the U.S. Bureau of the Census. Instead of using market valuation measures such as excess value of the firm he uses productivity measures of firm performance like total factor productivity (TFP). TFP measures of firm performance were obtained at the plant level by estimating a log-linear Cobb-Douglas production function for each industry and year. Number of segments and Herfindahl index were used as measures of diversification. He also controls for firm size and segment size in his regressions. Schoar (2002) examined several different hypotheses in his paper and uses 
different dummies to do so. Krishnaswami et al. (1999) empirically analyzed the information hypothesis that the separation of a firm's divisions into independently traded units through a spin-off enhances value because it mitigated information asymmetry about the firm. Consistent with this hypothesis, they reported that firms that engaged in spin-offs have higher levels of information asymmetry compared with their industry and size matched counterpartyed and the information problems decreased significantly after the spin-off. The gains around spin-offs were positively associated with the degree of information asymmetry, and this relationship was more pronounced for firms with fewer negative synergies between divisions. Finally, firms with higher growth opportunities and firms in need of external capital showed a higher propensity to engage in spin-offs. They also raised more capital following a spin-off, which is consistent with the view that these firms mitigate information asymmetry before approaching the capital market for funds (Scharfstein \& Stein, 1998, 2000).

Nayyar (1993) examined the performance effects of information asymmetry and economies of scope in diversified service firms. Tests using both accounting and stock market based measures of performance revealed that information asymmetry improved performance more than economies of scope. As hypothesized, the benefits of information asymmetry were greater for firms offering services whose quality cannot be determined until after their purchase (experience services), and the benefits of economies of scope were greater for firms offering services whose quality can be determined prior to purchase(search services). However, without considering the interactive effects of service characteristics, economies of scope were negatively associated with performance for diversified service firms overall (Jensen, 1986; Jensen \& Murphy, 1990).

Healy and Palepu (2001) investigated whether financial reporting and disclosure were potentially important means for management to communicate firm performance and governance to outside investors. They provided a framework for analyzing managers' reporting and disclosure decisions in a capital markets setting, and identified key research questions. They then reviewed current empirical research on disclosure regulation, information intermediaries, and the determinants and economic consequences of corporate disclosure. Their survey concluded that current research had generated a number of useful insights and identified many fundamental questions that remain unanswered, and changes in the economic environment that raise new questions for research.

Thomas and Fee (2000) reviewed whether or not there was any clear theoretical consensus about the overall effect of firm diversification on the magnitude of asymmetric information problems that firms face. They compared stock market based measures of asymmetric information for diversified firms with those they could reasonably expect to exhibit if they were split along industry lines into separately traded entities. They reported that approximately $74 \%$ of the diversified firms in their sample had less severe asymmetric information problems as conglomerates than they could expect to experience as separately traded pure-play firms. They also reported some evidence that diversified firms with low levels of information asymmetry trade at significant diversification premiums while diversified firms with high levels of information asymmetry trade at significant diversification discounts.

\section{Measuring Corporate Diversification, information asymmetry and Firm Performance}

Jacquemin and Berry (1979), Palepu (1985) and Hoskisson et al. (1993) indicated that the decomposition property of the entropy formula could help to analyze corporate diversification and its effect on corporate growth. Let $\mathrm{p}_{\mathrm{i}}$ stand for the proportion of a firm's total sales or production in the industry $i$. Entropy is computed again and now indicates corporate diversification. Zero entropy implies perfect specialization, while maximum entropy indicates maximum diversification. Based on the developments of the literature, in this paper we use entropy index for measuring diversification that defined by: 


$$
\text { ENTROP }=-\sum_{i=1}^{n} p_{i} \cdot \ln p_{i}
$$

The information asymmetry (STDRET): For calculate the information asymmetry used the standard deviation of daily stock returns (STDRET). Information asymmetry is the independent variable in this study.

Return on Assets (ROA): we use ROA as a measure of firm performance:

$$
R O A=\frac{\text { Profit to shareholders }}{\text { Total assets }}
$$

We used three variables as a control variables are as follows:

The size of firm (SIZE): It is essential to control the size of the firm sample that is supposed to act on the performance. We kept as variable of control the size of every firm measured by the logarithm of the total asset of the group.

The growth of the firm (GROWTH): The growth of the company is one of the explanatory factors the most important of the performance of firms. This variable is measured by the average variation of the turnover on the reporting period. That is:

$$
\text { GROWTH }=\frac{\text { Sales }_{\mathrm{n}}-\text { Sales }_{\mathrm{n}-1}}{\text { Sales }_{\mathrm{n}-1}}
$$

The debt (DEBT): The variable of the debt is measured as the ratio of the total debts and the shareholders equity.

This study implies that the impact of the information asymmetry and firm performance in firms of Tehran Stock Exchange.

\section{Research model and Hypothesis}

Based on the developments of the literature, several hypotheses are developed. The first hypothesis is about the effect of diversification on information asymmetry. It is stated:

$\mathbf{H}_{1}$ : The corporate diversification influences on information asymmetry.

The second hypothesis about the effect of diversification on performance is as follows:

$\mathbf{H}_{2}$ : The corporate diversification influences on firm performance.

This paper is broken into four substantive parts. Following this introductory section, the next section is associated with the proposed method, then we preset the results, and finally, concluding remarks are given in the last to summarize the contribution of the paper.

\section{Method and results}

As mentioned earlier, the sample is composed of 47 companies listed in Tehran Stock Exchange. The methodology for analyzing data is based on panel modeling. In the first, the Entropy index is computed again and now indicates corporate diversification. The data being in both time series and cross sectional. We have thus made regression using a panel data. 
Table 1 shows the descriptive statistics of the variables on the whole period (2008-2012): mean, median, maximum, minimum and standard deviation. The diversification variable is measured by Entropy Index (ENTROP). The performance is evaluated by the Return On Assets (ROA). The Information Asymmetry is measured by standard deviation of the return equity (STDRET). The log of total asset measures the size of the firm (SIZE). The (DEBT) variable corresponding to total debt/ total equity, presents the debt of the firm. The growth (GROWTH) is measured by the variation of the turnover of the company. The number of observation is 235.

Table 1

Descriptive Statistics

\begin{tabular}{lcccccc}
\hline Variables & N/valid & Mean & Median & Std. Dev. & Maximum & Minimum \\
\hline STDRET & 235 & 0.17 & 0.09 & 0.22 & 1.43 & 0.00 \\
Ln STDRET & 235 & -2.33 & -2.41 & 1.06 & 0.36 & -5.63 \\
ROA & 235 & 19.22 & 18.12 & 12.99 & 57.57 & -24.86 \\
ENTROP & 235 & 0.52 & 0.52 & 0.32 & 1.50 & 0.00 \\
DEBT & 235 & 0.59 & 0.58 & 0.17 & 1.00 & 0.16 \\
SIZE & 235 & 5.81 & 5.76 & 0.66 & 7.90 & 4.25 \\
GROWTH & 235 & 0.20 & 0.14 & 0.36 & 2.15 & -0.77 \\
\hline
\end{tabular}

\section{- Normal distribution of the dependent variables}

Normality of a regression model remaining is one of the regression assumptions that illustrates the validity of the regression tests. Using Kolmogrov-Smirnov test, the normality of dependent variables distribution is investigated. Since the normality of dependent variables leads to normality of remains of model (Difference between the estimated values of the real data), it is necessary to control the dependent variable before the estimate parameters. The null hypothesis and hypothesis 1 in this test is written as follow:

$\left\{\begin{array}{l}H_{0}: \text { Data for the dependent variable follows a normal distribution } \\ H_{1}: \text { Data for the dependent variable not follows a normal distribution }\end{array}\right.$

Meaningful values for return standard deviation (STDRET) variable during studied years is less than 0.05 so, null hypothesis is rejected for this variable. Normal distribution of variables in different years is not normal but the values of these variables logarithm in these years is more than 0.05 . Therefore, their distribution has been normal.

Table 2

Test Kolmogorov - Smirnov

\begin{tabular}{|c|c|c|c|c|c|c|c|c|}
\hline \multirow[b]{2}{*}{ Variables } & \multirow{2}{*}{ Number } & \multicolumn{2}{|c|}{ Normal parameters } & \multicolumn{3}{|c|}{ Most Extreme Differences } & \multirow{2}{*}{$\begin{array}{c}\text { Kolmogorov- } \\
\text { Smirnov Z }\end{array}$} & \multirow{2}{*}{$\begin{array}{c}\text { Asymp. } \\
\text { Sig. } \\
\text { (2-taile) }\end{array}$} \\
\hline & & Mean & Std. dev. & Absolute & Positive & Negative & & \\
\hline STDRET & 235 & 0.17 & 0.22 & 0.23 & 0.23 & -0.22 & 3.57 & 0.00 \\
\hline LnSTDRET & 235 & -2.33 & 1.06 & 0.04 & 0.04 & -0.04 & 0.58 & 0.89 \\
\hline ROA & 235 & 19.22 & 12.99 & 0.07 & 0.07 & -0.06 & 1.03 & 0.23 \\
\hline
\end{tabular}

In this study, we have two hypotheses. For each hypothesis, we analyze data.

\section{- Panel Analysis Hypothesis 1}

The study has used different effects namely, the panel analysis (Panel) without fixed effects, with fixed effects and with random effects. To determine the effectiveness of model with fixed or random effects, Limer (Chow) test and Houseman test have been used. As Table 3 shows, the results of Chow test indicate that the model with fixed effects is better than pooled model. 
The results of the first hypothesis test

Table 3

Limer(Chow) Test for Hypothesis 1

\begin{tabular}{llll}
\hline Effects Test & Statistic & d.f. & Prob. \\
\hline Cross- section F & 4.267 & $(46,184)$ & 0.000 \\
Cross- section Chi- square & 170.606 & 46 & 0.000 \\
\hline
\end{tabular}

We have also used Hausman test to determine whether the model with fixed effects is appropriate or model with random effects is suitable. As the results of Table 4 show, the results of Hausman test indicate that the model with random effects is appropriate. The significance level for the test of Hausman is 0.052, which indicates the model with random effects is appropriate. Table 4 shows the results.

\section{Table 4}

Hausman Test for Hypothesis 1

\begin{tabular}{lccc}
\hline Test Summary & Chi-Sq. Statistic & Chi-Sq. d.f & Prob. \\
\hline Cross- section random & 9.470 & 4 & 0.052 \\
\hline
\end{tabular}

The supposed model to test the first hypotheses is as follow:

$$
\operatorname{Ln}\left(\operatorname{STDRET}_{i t}\right)=\beta_{0}+\beta_{1} \text { Entropy }_{i t}+\beta_{2} \mathrm{DEBT}_{i t}+\beta_{3} \mathrm{SIZE}_{i t}+\beta_{4} \text { Growth }_{i t}+\varepsilon_{i t}
$$

The results of random effects show that probability of significant of $F$ is equal to 0.000 , which means the model is statistically significance. The coefficient of determination is equal to 0.088 . The tstatistics for ENTROP is equal to 2.01 (meaningful and positive), for SIZE is equal to -1.02 (meaningless), for DEBT is equal to -3.67 (meaningful and negative) and for GROWTH is equal to 2.45 (meaningful and negative). The results are shown in Table 5:

\section{Table 5}

Cross- section Random effects of Hypothesis 1

\begin{tabular}{lll}
\hline Variables & Coefficient & t-Statistics \\
\hline C & -0.915 & -0.992 \\
Entropy & 0.492 & 2.015 \\
DEBT & -1.475 & -3.673 \\
SIZE & -0.151 & -1.020 \\
GROWTH & 0.382 & 2.454 \\
\hline
\end{tabular}

$\mathrm{R}^{2}=0.088$, Prob(F- statistics) $=0.000$, Durbin- Watson stat $=1.139$

By controlling other variables, the results indicate when ENTROP increases one unit, STDRET is increased 0.49 .

\section{- Panel Analysis $\mathbf{H}_{2}$}

For data analysis, three methods of the panel analysis (Panel) without fixed effects, with fixed effects and with random effects have been used. To determine the effectiveness of model with fixed or random effects Limer (Chow) test and Houseman test have been used. As Table 6 shows, the results of chow test indicate that the model with fixed effects is better than pooled model.

\section{The results of the second hypothesis}

\section{Table 6}

Limer(chow) test for Hypothesis 2

\begin{tabular}{llll}
\hline Effects Test & Statistic & d.f. & Prob. \\
\hline Cross- section F & 7.493 & $(46,184)$ & 0.000 \\
Cross- section Chi- square & 248.035 & 46 & 0.000 \\
\hline
\end{tabular}


We have used Hausman test to determine whether the model with fixed effects is more appropriate or model with random effects. As the results of table 7 show, the results of Hausman test indicate that the model with random effects is appropriate. The significance level for the test of Hausman is 0.000, which indicates the model with fixed effects is more appropriate. Table 7 shows the results

\section{Table 7}

Hausman Test for Hypothesis 2

\begin{tabular}{lccc}
\hline Test Summary & Chi-Sq. Statistic & Chi-Sq. d.f & Prob. \\
\hline Cross- section random & 20.919 & 4 & 0.000 \\
\hline
\end{tabular}

The supposed model to test the hypotheses is as follow:

$$
R O A_{i t}=\beta_{0}+\beta_{1} \text { Entropy }_{i t}+\beta_{2} D E B T_{i t}+\beta_{3} S I Z E_{i t}+\beta_{4} \text { Growth }_{i t}+\varepsilon_{i t}
$$

The results of fixed effect show that probability of significant of $F$ is equal to 0.000 . This result means that the model is significant. The coefficient of determination is equal to 0.71 . The t-statistics for ENTROP is equal to 0.23(meaningless), for SIZE is equal to -2.87(meaningful and negative), for DEBT is equal to -3.66 (meaningful and negative) and for GROWTH is equal to -4.56 (meaningful and negative). The results are shown in Table 8:

\section{Table 8}

Cross- section Fixed effects of Hypothesis 2

\begin{tabular}{lcc}
\hline Variables & Coefficient & t-Statistics \\
\hline C & 105.355 & 3.904 \\
Entropy & 0.795 & 0.233 \\
DEBT & -19.399 & -3.664 \\
SIZE & -12.655 & -2.873 \\
GROWTH & -7.523 & -4.561 \\
\hline
\end{tabular}

$\mathrm{R}^{2}=0.710$, Prob(F- statistics) $=0.000$, Durbin- Watson stat $=1.547$

By controlling other variables, the results indicate when ENTROP increases or decreases one unit, ROA will not change.

\section{Discussion and Conclusion}

In this paper, we have investigated the evolution of the strategic business perimeter of the firms of Tehran Stock Exchange on a sample of 47 large firms over the period 2008-2012. This paper has examined the effect of corporate diversification on information asymmetry and firm performance. To examine the firm performance, we have used return on assets. The results have shown that corporate diversification influenced on information asymmetry. In addition, the results have shown that corporate diversification influenced on firm performance. The researchers can choose the greater number of companies and use other methods for evaluation of firm performance and information asymmetry. In addition, the researcher can choose other independent variables and examine the corporate diversification on other dependent variables.

\section{References}

Amihud, Y., \& Lev, B. (1981). Risk reduction as a managerial motive for conglomerate mergers. The Bell Journal of Economics, 12(2), 605-617.

Amit, R., Ding, Y., Villalonga, B., \& Hua, Z. (2010). The role of institutional development in the prevalence and value of family firms. In Finance and corporate governance conference.

Barney, J. B., \& Hesterly, W. S. (2008). Strategic management and competitive advantage: concepts. Pearson/Prentice Hall. 
Berger, P. G., \& Ofek, E. (1995). Diversification's effect on firm value. Journal of financial economics, 37(1), 39-65.

Choe, C., Tian, G. Y., \& Yin, X. (2009). Managerial power, stock-based compensation, and firm performance: theory and evidence. Stock-Based Compensation, and Firm Performance: Theory and Evidence (February 1, 2009).

Choe, C., \& Yin, X. (2009). Diversification discount, information rents, and internal capital markets. The Quarterly Review of Economics and Finance, 49(2), 178-196.

Gomes, J., \& Livdan, D. (2004). Optimal diversification: Reconciling theory and evidence. The Journal of Finance, 59(2), 507-535.

Healy, P. M., \& Palepu, K. G. (2001). Information asymmetry, corporate disclosure, and the capital markets: A review of the empirical disclosure literature. Journal of accounting and economics, 31(1), 405-440.

Hoskisson, R.E., Hitt, M.A., Johnson, R.A., \& Moesel, D.D. (1993). Construct-validity of an objective (entropy) categorical measure of diversification. Strategic Management Journal, 14(3), 215-235.

Jacquemin, A.P., \& Berry, C.H. (1979). Entropy measure of diversification and corporate growth. Journal of Industrial Economics, 27(4), 359-369.

Jensen, M. C. (1986). Agency costs of free cash flow, corporate finance, and takeovers. The American Economic Review, 76(2), 323-329.

Jensen, M. C., \& Murphy, K.J. (1990). Performance pay and top-management incentives. The Journal of Political Economy, 98(2), 225-264.

Khanna, T., \& Palepu, K. (2000). Is group affiliation profitable in emerging markets? An analysis of diversified Indian business groups. The Journal of Finance, 55(2), 867-891.

Krishnaswami, S., Spindt, P. A., \& Subramaniam, V. (1999). Information asymmetry, monitoring, and the placement structure of corporate debt. Journal of Financial Economics, 51(3), 407-434.

Mansi, S. A., \& Reeb, D.M. (2002). Corporate diversification: What gets discounted?. The Journal of Finance, 57(5), 2167-2183.

Martin, J. D., \& Sayrak, A. (2003). Corporate diversification and shareholder value: a survey of recent literature. Journal of Corporate Finance, 9, 37-57.

Maksimovic, V., \& Phillips, G. (2007). Conglomerate firms and internal capital markets. in B.E. Eckbo, ed., Handbook of Corporate Finance, 1, Elsevier B.V.

Matsusaka, J. G. (1993). Takeover motives during the conglomerate merger wave. The RAND Journal of Economics, 24(3), 357-379.

Matsusaka, J. G. (2001). Corporate diversification, value maximization, and organizational capabilities. The Journal of Business, 74(3), 409-431.

Nayyar, P. R. (1993). Performance effects of information asymmetry and economies of scope in diversified service firms. Academy of Management Journal, 36(1), 28-57.

Palepu, K. (1985). Diversification strategy, profit performance and the entropy measure. Strategic Management Journal, 6, 239-255.

Palich, L. E., Cardinal, L. B., \& Miller, C. C. (2000), Curvilinearity in the diversification performance linkage: an examination of over three decades of research. Strategic Management Journal, 21(2), 155-174.

Rajan, R., Servaes, H., \& Zingales, L. (2000). The cost of diversity: the diversification discount and inefficient investment. Journal of Finance, 55, 35-80.

Rajan, R., \& Zingales, L. (2000). The tyranny of inequality. Journal of Public Economics, 76, 521558.

Solomon, J., \& Solomon, A. (2004). Corporate Governance \& Accountability. John Wiley \& Sons, Ltd.

Shleifer, A., \& Vishny, R.W. (1989). Management Entrenchment: the case of manager specific investment. Journal of Financial Economics, 25, 123-139.

Shleifer, A., \& Vishny, R.W. (1992). Liquidation values and debt capacity: A market equilibrium approach. The Journal of Finance, 47(4), 1343-1366. 
Scharfstein, D. S. (1998). The dark side of internal capital markets II: Evidence from diversified conglomerates. NBER Working Paper Series, 6352.

Scharfstein, D. S., \& Stein, J.C. (2000). The dark side of internal capital markets: divisional Rentseeking and inefficient investment. Journal of Finance, 55, 2537-2564.

Schoar, A. (2002). Effects of corporate diversification on productivity. The Journal of Finance, 57(6), 2379-2403.

Stein, J. C. (1997). Internal capital markets and the competition for corporate resources. Journal of Finance, 52, 111-133.

Stein, J. C. (2003). Agency, information and corporate investment. in G. M. Constantinides, M. Harris and R. Stulz, ed., Handbook of the Economics of Finance, Elsevier Science B.V.

Sunder, S. (1997). Theory of accounting and control. South-Western College Pub.

Teece, D. J. (1980). Economies of scope and the scope of the enterprise. Journal of Economic Behavior \& Organization, 1(3), 223-247.

Teece, D. J. (1982). Towards an economic theory of the multiproduct firm.Journal of Economic Behavior \& Organization, 3(1), 39-63.

Thomas, S., \& Fee, C. E. (2000). Corporate Diversification, Asymmetric Information, and Firm Value: Evidence from Stock Market Trading Characteristics. Asymmetric Information, and Firm Value: Evidence from Stock Market Trading Characteristics.

Tirole, J. (1988). The Theory of Industrial Organization: Jean Tirole. MIT press.

Velleman, P. F., \& Hoaglin, D. C. (1981). Applications, basics, and computing of exploratory data analysis (Vol. 142). Boston: Duxbury Press.

Villalonga, B. (2000). An empirical analysis of diversification motives. Unpublished manuscript, University of California, Los Angeles.

Villalonga, B. (2003). Research Roundtable Discussion: The Diversification Discount. Harvard Business School.

Villalonga, B. (2004). Diversification discount or premium? New evidence from the business information tracking series. The Journal of Finance, 59(2), 479-506. 